\title{
Argatroban in HIT Type II and Acute Coronary Syndrome
}

\author{
Bruce E. Lewis ${ }^{a}$ Jeanine M. Walenga ${ }^{b}$ \\ a Loyola University Medical Center, Maywood, III., Catholic Health Partners, Chicago, III.; \\ bThoracic and Cardiovascular Surgery and Pathology, Loyola University Medical Center, Maywood, III., USA
}

\section{Key Words}

Argatroban - Thrombin inhibitor · Heparin antibody •

Acute coronary syndrome

\begin{abstract}
Prior to initiation of the ARG-911 and ARG-915 clinical trials, there was no optimal replacement for heparin anticoagulation in patients with heparin-induced thrombocytopenia (HIT) type II. These prospective, historical controlled studies were designed to determine the usefulness of argatroban, a direct thrombin inhibitor (DTI) that is not immunogenic and does not interact with heparin antibody, in answering this clinical need. Clinical outcomes (37-day period) for 568 argatroban-treated and 193 control patients demonstrated significantly reduced risks of the primary efficacy composite endpoint (allcause death, all-cause amputation, new thrombosis) and the secondary endpoints (death due to thrombosis, new thrombosis) with argatroban. Argatroban patients also experienced a more rapid recovery of platelet count. Bleeding events were similar among both groups. It was concluded that argatroban anticoagulation, compared with historical controls, improves clinical outcomes without increasing bleeding risk in patients having HIT with or without thrombosis. Argatroban has since been approved in the US for both prophylaxis and treatment of thrombosis in patients with HIT. Argatroban has been
\end{abstract}

used in percutaneous coronary interventions in patients with and without HIT, for peripheral vascular procedures in both large and small vessels in HIT patients, and as an adjunct to thrombolytic therapy for the treatment of AMI. Treatment success rates and the same or less bleeding was demonstrated with argatroban compared to heparin controls. These pilot studies suggest that argatroban will provide reliable anticoagulation during interventional procedures. A consistent safety profile of argatroban has been demonstrated in all studies to date. The main attributes of argatroban are its rapid onset of action, fast reversibility of its anticoagulant effect, inhibition of clotbound thrombin, easily monitored by the aPTT and ACT and no dosage adjustment in renal-impaired individuals. These properties make argatroban a predictable and useful anticoagulant for HIT and non-HIT patients.

Copyright $@ 2002$ S. Karger AG, Basel

\section{Introduction}

Argatroban is a small molecule direct thrombin inhibitor (DTI). This drug has been used in Japan for the management of thromboembolic disorders for over 10 years. Despite this and a large number of preclinical studies on the pharmacology of argatroban, clinical trials for argatroban in Europe and North America were only initiated in 1993.

\section{KARGER \\ Fax +4161306 1234 \\ E-Mail karger@karger.ch \\ www.karger.com

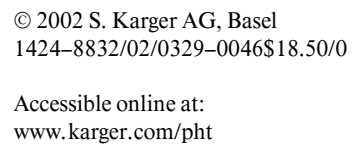

Jeanine M. Walenga, $\mathrm{PhD}$

Cardiovascular Institute, Loyola University Medical Center

2160 S. First Ave.

Maywood, IL 60153 (USA)

Tel. +1 708327 2838, Fax +1 708327 2849, E-Mail jwaleng@lumc.edu 
Argatroban is of a class of drugs that differs in many respects from heparin, low molecular weight heparins and heparinoids [1-5]. Many of the characteristics common to thrombin inhibitors make argatroban beneficial for use as an anticoagulant in patients with heparin-induced thrombocytopenia (HIT). These attributes include no crossreactivity with heparin antibody, no potentiation of HIT and absence of antibody formation (tables 1,2).

The clinical utility of argatroban for the management of patients with HIT-associated thrombosis and in the setting of interventional cardiology will be reviewed.

\section{Argatroban for HIT}

\section{Pathophysiology of HIT}

HIT, type II, is a disease spectrum triggered by an immune response to heparin. HIT occurs in approximately $2 \%$ of all heparin-treated individuals. The currently

Table 1. Pharmacologic characteristics of argatroban

Selective, direct inhibitor of thrombin

Rapid onset of action

Rapidly reversed

Short half-life ( $\sim 45 \mathrm{~min}$ i.v.)

Clearance through the liver

No need for dosage adjustment in renal-impaired patients

Inhibition of clot-bound thrombin

Not dependent on cofactors (e.g., AT, HCII)

Easily monitored by aPTT or ACT

Lesser bleeding risk than other DTIs

No cross-reactivity with heparin antibody

Absence of antibody formation that affect pharmacokinetics/ activity accepted hypothesis of the pathophysiology of HIT is based on the development of an IgG antibody to the heparin-PF4 complex that recognizes the Fc $\gamma$ RIIa receptor on platelets. Binding of the IgG complex causes platelet activation, aggregation and thrombin generation [6-10]. The antibody is not heparin specific, and has been shown to react with other highly sulfated materials $[11,12]$. Other antibodies have been identified.

The $\mathrm{IgG}$ antibody binding to heparin-PF4 will also target PF4 bound to endothelial cell heparan sulfate [13-15]. Damaged endothelial cells can act as a starting point for the thrombotic event potentially through exposure of tissue factor that is enhanced by recruited monocytes and further tissue factor release from endothelial cells $[13,15-$ 17]. The release of platelet microparticles rich in phospholipid further contributes to platelet aggregation, endothelial cell activation and thrombin generation $[17,18]$. Evidence of important platelet-leukocyte activation suggests an interaction of hemostatic activation with an inflammatory process in HIT $[19,20]$.

Thus, the pathophysiological mechanism of HIT is characterized by platelet activation, thrombin generation, endothelial cell activation/injury and leukocyte activation [21].

\section{Clinical Diagnosis of HIT}

The diagnosis of HIT is often not easy or straightforward. Clinical criteria are most important, including platelet count and evidence of unexplained thrombosis. However, HIT can be present even with a normal platelet count [22-24]. Confirmation by specific laboratory tests is optimal but not always possible. Rechallenge with heparin after resolution of the thrombocytopenia to confirm the diagnosis of HIT is dangerous and should not be performed.

Table 2. Differences between the two DTIs argatroban and hirudin

\begin{tabular}{ll}
\hline Argatroban & Hirudin \\
\hline $\begin{array}{l}\text { Shorter half-life } \\
\text { Anticoagulant response rapidly reversed }\end{array}$ & $\begin{array}{l}\text { Longer half-life } \\
\text { Anticoagulant response slowly reversed } \\
\text { No antibody formation to argatroban }\end{array}$ \\
$\begin{array}{l}\text { Antibodies are generated that delay its elimination; anti- } \\
\text { bodies are generated that decrease its anticoagulant activity } \\
\text { May have less bleeding side effects }\end{array}$ & $\begin{array}{l}\text { Cleared via the kidney } \\
\text { Metabolized in the liver }\end{array}$ \\
$\begin{array}{l}\text { Requires dose adjustment in liver disease patients } \\
\text { Effectively monitored by aPTT and ACT }\end{array}$ & $\begin{array}{l}\text { Monitored by aPTT and ACT, but response times are differ- } \\
\text { ent from argatroban }\end{array}$ \\
&
\end{tabular}

Argatroban in HIT Type II and Acute

Coronary Syndrome
Pathophysiol Haemost Thromb

2002;32(suppl 3):46-55 
The most dramatic clinical expression of HIT is HIT antibody-driven thrombosis. HIT is probably a more common cause of thrombosis than has been appreciated. The majority of cases of HIT are found in medically and surgically treated adults but can also be observed from simple catheter line flush heparin [25], during pregnancy and in children. Postoperative coronary artery bypass patients have a high frequency of venous graft closure. Additionally, outpatients can develop thrombosis in the home setting.

Patients with clinically diagnosed HIT have a 35\% probability of developing a clinically significant thrombosis during their hospitalization [22, 26, 27]. Patients with HIT associated thrombosis have a mortality rate of 25$30 \%$ and an amputation rate of $25 \%$.

Thrombosis can occur anywhere throughout both the venous and the arterial circulation [22-24, 26]. Recent reports document a higher frequency of venous thrombosis than arterial thrombosis [26]. HIT-associated thrombosis is most commonly associated with deep vein thrombosis and pulmonary embolism, but unusual thromboses, including e.g., mesenteric ischemia, which is commonly overlooked, spinal artery thrombosis, visceral infarctions, cerebral infarction and myocardial infarction are not uncommon. Mesenteric infarction has been seen in $15 \%$ of patients, myocardial infarction in $20 \%$ and cerebral infarction in $10 \%$.

\section{Laboratory Diagnosis of HIT}

There is no highly sensitive and specific laboratory test for HIT [28, 29]. The functional platelet aggregation assay using patient serum (antibody), heparin and donor platelets has several limitations including a high false-negative rate. The serotonin release assay (SRA) using washed donor platelets radiolabeled with ${ }^{14} \mathrm{C}$-serotonin, patient serum and heparin has a higher sensitivity of $60-80 \%$. Yet there can be patient samples negative by SRA that are positive by the aggregation test. Both the SRA and the aggregation assay are characterized by technical difficulties that require expert lab staff.

There are two Elisa tests for quantitating the antibody titer to the heparin-PF4 complex (Stago, Asnières, France and GTI, Brookfield, Wisc., USA). A minimum critical titer has not been identified that is associated with HIT thrombosis [28]. Heparin or low molecular weight (LMW) heparin treatment alone provokes antibody production that is not accompanied by thrombocytopenia or thrombosis [24, 29-32]. This common finding can lead to inappropriate treatment in patients who do not have HIT. On the other hand, patients clinically positive for HIT do not necessarily have positive Elisa antibody titers [28, 33]. Thus, although the Elisa is easy to perform, it does not provide results that are always clinically relevant.

As yet, there is no single assay that is ideal for diagnosing HIT. Each of the current assays for HIT contributes independent information. None can be used alone with complete confidence to identify a HIT-positive patient. Clinically positive patients could be missed by all assays, and antibody alone (Elisa positive) does not determine clinical HIT. Use of the Elisa method as a stand-alone test or as a rapid, preliminary screening test for HIT with confirmation by a follow-up SRA test should be discouraged. The combination of platelet aggregation, SRA and Elisa testing, with multiple samples, offers the best chance of identifying a positive HIT patient. Clinical observations remain of foremost importance in diagnosing HIT.

\section{Clinical Management of HIT}

The apparent paradox of a fall in platelet count with thrombotic rather than hemorrhagic complications is analogous to the syndrome of thrombotic thrombocytopenic purpura [23, 24]. HIT is clinically managed as an allergy to heparin. All heparin is immediately discontinued upon suspicion of the disease with a meticulous search for all sources of exogenous heparin. Due to the high probability of thrombosis, a vigorous search for venous and arterial thrombosis should be undertaken.

Unfortunately, early discontinuation of heparin does not significantly reduce the incidence of morbidity and mortality in patients with HIT [26]. It may be appropriate to use antithrombotic drugs as prophylaxis against thrombosis in this high-risk population. This practice has not been common, but this may relate more to the lack of appropriate prophylactic agents for this patient population than to the medical rationale. Today, use of a DTI can be recommended, initiated at a low level of anticoagulation until the thrombocytopenia resolves for patients with HIT antibody despite no other indication for anticoagulation. For patients with HIT-associated thrombosis, there is an immediate need to treat to avoid propagation of the clot or development of pulmonary embolism.

Other considerations for anticoagulation needs in the patient with HIT include patients with thrombosis for non-HIT-related events, such as myocardial infarction, unstable angina, heart valves and atrial fibrillation. Perhaps the greatest obstacle to overcome in the management of these patients is anticoagulation for coronary revascularization or cardiac surgery. For a short period, heparin has been used in patients who have negative antibody titers, albeit with some risk [23].
48

Pathophysiol Haemost Thromb 2002;32(suppl 3):46-55
Lewis/Walenga 


\section{Traditional Therapies}

The conventional anticoagulants aspirin and dextran are of limited value in the treatment of patients with HITassociated thrombosis (table 3) [24, 34]. Coumadin derivatives require a loading period that leaves patients without anticoagulant protection for 48-72 h. Coumadin derivatives also inhibit protein $\mathrm{C}$, potentially resulting in a prothrombotic state. Because of this, it is recommended that coumadin derivatives be initiated at low doses only when patients are out of the acute phase of HIT when platelet counts are on the rise [34].

Patients who have limb-threatening or life-threatening thrombosis can be treated with selective thrombolytic infusion, e.g., lower dose for postoperative patients and higher dose for non-postoperative patients $[35,36]$ until angiographic evidence of complete resolution of thrombus. Surgical thrombectomy remains a reasonable therapy in patients who have dire clinical circumstances and cannot afford the time required for selective thrombolytic infusions [23, 24]. However, the endothelial damage that occurs with thrombectomy, combined with the involvement of HIT antibody on endothelial cells, may explain the limited success with thrombectomy.

Anticoagulants other than heparin are necessary for proper treatment of patients with HIT (table 3 ). The early treatment alternatives have been less than optimal due to high bleeding risk, slow onset of action, long half-life, poor efficacy and lack of an antidote. These options have included the defibrinating agent ancrod (Arvin ${ }^{\circledR}$; Knoll, Whippany, N.J., USA) [37, 38], and the heparinoid danaparoid (Orgaran ${ }^{\circledR}$; Organon, Oss, The Netherlands) [39]. It has also been shown that heparin antibodies can crossreact with danaparoid [40].

LMW heparins appear to be less likely than heparin to cause HIT [31]; however, in vitro results unequivocally demonstrate that the heparin antibody recognizes LMW heparin producing platelet aggregation in a heparin-antibody-stimulated system [12, 40, 41]. Thus, LMW heparins should not be administered to patients with known heparin antibody.

Argatroban, a Direct Thrombin Inhibitor

An anticoagulant of a structure different from heparin, that has no ability to cross-react with the HIT antibody, would be the drug of choice for patients with HIT. The most promising class of drugs to date for treatment of patients with HIT are the DTIs. Argatroban (GlaxoSmithKline, Philadelphia, Pa., USA) is approved for the prophylaxis and treatment of HIT thrombosis in the USA. Among other beneficial characteristics, this
Table 3. Anticoagulants for the treatment of thrombosis in patients with HIT

\begin{tabular}{ll}
\hline Drug & Status \\
\hline Warfarin and dextran & $\begin{array}{l}\text { limited efficacy; warfarin can be } \\
\text { useful for long-term management } \\
\text { after thrombin inhibitor treat- } \\
\text { ment during acute phase }\end{array}$ \\
\hline $\begin{array}{l}\text { Selective thrombolytic infusion } \\
\text { or surgical thrombectomy }\end{array}$ & $\begin{array}{l}\text { useful for life-threatening throm- } \\
\text { bosis only }\end{array}$ \\
\hline Ancrod (defibrinating agent) & $\begin{array}{l}\text { difficult dosing regimen; slow on- } \\
\text { set of action; high bleeding risk; } \\
\text { no antidote }\end{array}$ \\
\hline Danaparoid (heparinoid) & $\begin{array}{l}\text { monitoring not convenient; long } \\
\text { half-life; high bleeding risk at high } \\
\text { dose; no antidote; may cross-react } \\
\text { with heparin antibody }\end{array}$ \\
\hline Direct thrombin inhibitors & drug of choice \\
\hline Factor Xa inhibitors & investigational \\
\hline Anti-platelet drugs & $\begin{array}{l}\text { investigational, alone or in com- } \\
\text { bination with thrombin inhibitors }\end{array}$ \\
\hline ADP receptor inhibitors & \\
\hline
\end{tabular}

drug does not cross-react with the heparin antibody as shown by in vitro data and successful treatment of HIT patients (table 1) [12, 19, 42].

The ARG-911 was a multi-center study conducted to evaluate the safety and efficacy of argatroban in patients with HIT (table 4) [42]. Continuous intravenous argatroban was administered at $2 \mu \mathrm{g} / \mathrm{kg} / \mathrm{min}$ continuous infusion for an average of 6 days (14 days maximum) to 304 HIT patients. Dosage was adjusted to maintain the activated partial thromboplastin time (aPTT) between 1.5-3.0 $\times$ baseline. Because there was no approved alternative agent for use as an active comparator when the studies were conducted, a historical control was used for comparison $(\mathrm{n}=193)$.

Outcomes were assessed during and following therapy (37 days). The primary efficacy composite endpoint (new thrombosis, all-cause amputation, or all-cause death) was reduced significantly in argatroban-treated patients $(\mathrm{n}=$ $160)$ vs. controls $(n=147)$ with HIT $(25.6$ vs. $38.8 \%$, $\mathrm{p}=0.014)$. In patients with heparin-induced thrombocytopenia thrombosis syndrome (HITTS), the composite incidence in argatroban-treated patients was $43.8 \%(\mathrm{n}=$ $144)$ vs. $56.5 \%(n=46), p=0.131$. Significant betweengroup differences by time-to-event analysis of the com- 
Table 4. Summary of the ARG-911 clinical trial of argatroban anticoagulation for patients with HIT and HITTS

\section{HIT}

HITTS

Efficacy ( $p$ values in favor of argatroban over control)

Composite endpoint $^{1} \quad 0.014$

Time to event $\quad 0.01$

New thrombosis $\quad<0.001$

Death

$<0.005$

0.131

0.014

0.044

$<0.001$

Safety ( $p$ values in favor of argatroban over control)

Major bleeding $\quad 0.078$

Minor bleeding

NS

Rapid rise in platelet count

0.001

0.077

NS

Therapeutic level achieved within 4-5 h

1 New thrombosis, all-cause amputation, all-cause death [42].

HIT was defined in this study as heparin induced thrombosis without new thrombosis after heparin initiation (latent HIT). HITTS was defined as heparin induced thrombosis complicated by thrombosis that occurred after heparin administration. posite endpoint favored argatroban treatment in HIT ( $p=$ $0.01)$ and HITTS $(\mathrm{p}=0.014)$ patients. Argatroban therapy, relative to controls, also significantly reduced any new thrombosis $(\mathrm{p}<0.001$ in HIT and $\mathrm{p}=0.044$ in HITTS patients) and death due to thrombosis ( $p<0.005$ in HIT and $\mathrm{p}<0.001$ in HITTS patients).

No difference was detected in the incidence of major bleeding (HIT: $3.1 \%$ for argatroban vs. $8.2 \%$ for control, $\mathrm{p}=0.078$; HITTS: $11.1 \%$ for argatroban vs. $2.2 \%$ for control, $\mathrm{p}=0.077$ ). Minor bleeding was similar in both arms (HIT: $40.0 \%$ for argatroban vs. $40.8 \%$ for control; HITTS: $41.7 \%$ for argatroban vs. $41.3 \%$ for control). Argatrobantreated patients achieved therapeutic aPTTs generally within $4-5 \mathrm{~h}$ of starting therapy. Compared to historic controls, argatroban-treated HIT and HITTS patients had a significantly more rapid rise in platelet count by day 3 $(\mathrm{p}=0.0001)$.

This pivotal study showed that anticoagulation with argatroban significantly reduced the risk of thrombosis and thromboembolic complications of HIT/HITTS. This benefit was achieved without an increase in major bleeding. Based on the ARG-911 and a related clinical trial (ARG-915; $n=264$ ) in which a total of 568 adult patients were treated with argatroban, the US FDA granted approval for the use of argatroban for both prophylaxis and treatment of thrombosis associated with HIT.
Argatroban in Comparison to Hirudin

Hirudin (lepirudin, Refludan ${ }^{\circledR}$; Berlex, Wayne, N.J., USA) is another direct thrombin inhibitor. It is approved for treatment of HIT-associated thrombosis in the USA and Europe [43, 44], as DTIs hirudin and argatroban are similar. However, there are several pharmacologic characteristics that differ between the two drugs (table 2). Argatroban has a rapid onset of action, and it is rapidly dissociated from thrombin [2, 3, 45-48]. Argatroban has a shorter half-life than that of hirudin. The shorter half-life of argatroban seems to provide for easy clinical administration of the drug ('turn on-turn off') which seems to be reflected in a wider safety net (lesser bleeding) than that of hirudin. Argatroban is cleared through the liver; hirudin is cleared through the kidney. Hirudin is a protein and can generate antibodies that increase its anticoagulant activity by prolonging the half-life or antibodies that decrease its anticoagulant effect [49]. Argatroban does not induce antibody generation [50].

\section{Argatroban with Coumadin Derivatives}

For documented clinical thrombosis associated with HIT, patients should be treated with a DTI at therapeutic aPTT levels for 7-10 days. For patients with HIT and an underlying hypercoagulable state, mechanical prosthetic valves or atrial fibrillation, the ideal management strategy would be to initiate oral anticoagulation while maintaining a therapeutic level of anticoagulation with an intravenous DTI. To avoid skin necrosis, full anticoagulation with coumadin should not be achieved until platelet counts exceed 100,000/ $\mu 1$ [34]. Once the INR for coumadin is stable in the therapeutic range, the intravenous DTI can be tapered off then discontinued. Low dose aspirin can be added to the regimen once coumadin is therapeutic.

Argatroban is easily monitored by the aPTT $[1,42,46$, $51,52]$. But one should be aware that the prothrombin time (PT)/International Normalized Ratio (INR) is also affected by DTIs [51, 53, 54]. Higher than expected INR values will be obtained for patients on a combination of DTI and coumadin but without the same relationship between INR and bleeding risk. A nomogram is available that can be used to help direct dosing. A practical recommendation is to co-administer the drugs until an INR of 4 is achieved. Argatroban can then be withdrawn and the INR reassessed. Another recommendation is to utilize the short half-life of argatroban. If clinically practical, blood for the INR assessment can be drawn after the argatroban infusion has been interrupted for $2 \mathrm{~h}$. \begin{tabular}{ll}
\hline 50 & \\
Pathophysiol Haemost Thromb \\
$2002 ; 32(\operatorname{suppl} 3): 46-55$
\end{tabular}
Lewis/Walenga 
Table 5. Summary of the pilot cardiology studies of argatroban a Angioplasty: ARG-216/310/311

\begin{tabular}{lcc}
\hline & Argatroban & Heparin \\
\hline Acute procedural success, \% & 94.5 & 94.0 \\
Major bleeding, \% & 1.1 & 3.1 \\
\hline
\end{tabular}

b Acute myocardial infarction: MINT; ARGAMI

\begin{tabular}{|c|c|c|c|c|c|}
\hline & & & \multicolumn{2}{|c|}{ Argatroban } & \multirow[t]{2}{*}{ Heparin } \\
\hline & & & low dose ${ }^{1}$ & high dose ${ }^{2}$ & \\
\hline \multirow{4}{*}{\multicolumn{3}{|c|}{$\begin{array}{l}\text { Acute procedural success, patients presenting within } 6 \mathrm{~h}, \% \\
\text { Acute procedural success, patients presenting within } 3 \mathrm{~h}, \% \\
\text { Composite endpoint at } 30 \text { days, } \% \\
\text { Major bleeding, } \%\end{array}$}} & 56.8 & 58.7 & 42.1 \\
\hline & & & - & 57.1 & $20.0 *$ \\
\hline & & & 32.0 & 25.5 & 37.5 \\
\hline & & & 2.6 & 4.3 & 10.0 \\
\hline & $\begin{array}{l}\text { Argatroban } \\
\text { high dose }\end{array}$ & \multicolumn{3}{|c|}{ Heparin } & \\
\hline Acute procedural success, $\%$ & 76 & \multicolumn{3}{|c|}{82} & \\
\hline Major bleeding, $\%$ & 19.5 & \multicolumn{3}{|c|}{20.0} & \\
\hline
\end{tabular}

Argatroban achieved adequate anticoagulation within $10 \mathrm{~min}$ of initiation. $* \mathrm{p}=0.03$.

$350 \mu \mathrm{g} / \mathrm{kg}$ bolus plus $25 \mu \mathrm{g} / \mathrm{kg} / \mathrm{min}$ infusion.

$100 \mu \mathrm{g} / \mathrm{kg}$ bolus plus $1 \mu \mathrm{g} / \mathrm{kg} / \mathrm{min}$ infusion for $48-72 \mathrm{~h}$

$100 \mu \mathrm{g} / \mathrm{kg}$ bolus plus $3 \mu \mathrm{g} / \mathrm{kg} / \mathrm{min}$ infusion for $48-72 \mathrm{~h}$.
Argatroban with Anti-Platelet Drugs

Despite the potent anticoagulant effect of DTIs as seen in the clinical trials, there remains an unacceptable level of thrombosis-related morbidity and mortality in HIT patients. The glycoprotein (GP) IIb/IIIa platelet receptor inhibitors (abciximab, eptifibatide and tirofiban) and the ADP platelet receptor inhibitor (clopidogrel) have been shown to inhibit the in vitro platelet activation and aggregation responses induced by HIT serum and heparin [15, $17,19,55]$. This includes inhibition of the formation of thrombogenic platelet microparticles. The DTIs were not effective in suppressing this platelet activation.

Limited clinical experience suggests that a GPIIb/IIIa inhibitor as an adjunct to a DTI is effective at reducing thrombus that is resistant to DTI treatment alone [19]. A standard dose of a GPIIb/IIIa inhibitor can be administered with a reduced dose of the DTI. In a small group of HIT patients treated as such, there was no overt bleeding that required intervention and all patients exhibited clinical improvement or full recovery. Although promising, optimal dosing for this combination regimen has not yet been established.

\section{Argatroban for Acute Coronary Syndrome}

\section{Percutaneous Coronary and Peripheral Intervention}

Frequently, patients with HIT require coronary interventional procedures. The feasibility of using argatroban in this patient population was established several years ago [56-58]. Subsequently, two trials (ARG216 and ARG310/311) assessed the safety and efficacy of argatroban as anticoagulant therapy for percutaneous coronary interventional (PCI) procedures, including percutaneous transluminal coronary angioplasty, stent implantation or rotational atherectomy, on HIT patients (table 5) [59]. Patients ( $\mathrm{n}=91 ; 112$ PCIs) were given $350 \mu \mathrm{g} / \mathrm{kg}$ bolus argatroban followed by a $25 \mu \mathrm{g} / \mathrm{kg} / \mathrm{min}$ infusion. Efficacy of anticoagulation for argatroban-treated PCI HIT patients was measured by comparison to the Cleveland Clinic PCI angioplasty registry of heparin-treated nonHIT patients during the concordant time of patient enrollment. Safety of argatroban for PCIs was assessed by comparing the bleeding rate with argatroban to the heparin only arm of the EPILOG trial, which was also conducted during the same time period as patient enrollment in the argatroban PCI trials. 
The $94.5 \%$ acute procedural success rate with argatroban compared favorably with the $94.0 \%$ procedural success rate with heparin in patients undergoing their initial PCI with argatroban. No unsatisfactory outcomes occurred during repeat PCIs with argatroban $(n=21)$. Only 1 patient experienced major peri-procedural bleeding. The safety of argatroban during PCI was at least equivalent to that of heparin during PCI (1.1\% major bleed rate with argatroban vs $3.1 \%$ with heparin).

Adequate anticoagulation as measured by the activated clotting time (ACT) was achieved in $97.8 \%$ of argatroban-treated patients after the initial argatroban bolus. The target ACT for PCI of 300-450 s was achieved within 10 min of initiation of argatroban [57]. An ACT of $>300 \mathrm{~s}$ was maintained throughout the interventional procedure in over $80 \%$ of the argatroban-treated patients. A repeat argatroban bolus of $150 \mu \mathrm{g} / \mathrm{kg}$ generally re-established a therapeutic ACT. An ACT of 200-250 s is recommended when argatroban is used in conjunction with a GPIIb/IIIa inhibitor.

Argatroban has also been used for PCI in a limited number of non-HIT patients [1, 60-62]. Three studies reported procedural success in all patients. Argatroban produced predictable anticoagulation and was generally safe and well tolerated.

Although the data are promising for the use of argatroban in PCI in HIT and non-HIT patients, the registry style control data collection used in some of these studies could have introduced observational bias due to the nonblinded nature of the study design. Argatroban is indicated as an anticoagulant in patients with or at risk for HIT undergoing PCI. (Source: Argatroban US prescribing information leaflet, April 2002.)

The use of argatroban for peripheral vascular procedures including carotid and renal arteries as well as cerebral vessels has not been formally studied; however, a number of case reports provide some information regarding the feasibility of argatroban in these situations $[58,63$, 64]. Small vessel interventions on tibial and peroneal arteries or intracranial vessels can probably be safely performed using coronary argatroban dosing strategies ( $350 \mu \mathrm{g} / \mathrm{kg}$ bolus followed by $25 \mu \mathrm{g} / \mathrm{kg} / \mathrm{min}$ infusion). Larger vessels such as iliac and renal arteries can probably be treated with lesser argatroban doses $(250 \mu \mathrm{g} / \mathrm{kg}$ bolus followed by $10 \mu \mathrm{g} / \mathrm{kg} / \mathrm{min}$ infusion).

\section{Acute Myocardial Infarction}

The investigation of argatroban as adjunct therapy to thrombolytics for patients with acute ST elevation myocardial infarction (MI) was performed in a three-arm clin- ical study, the MINT trial (Myocardial Infarction with Novastan and tPA) [65]. Patients, within $6 \mathrm{~h}$ of onset of symptoms for AMI, were randomized to low-dose argatroban $(100 \mu \mathrm{g} / \mathrm{kg}$ bolus plus $1 \mu \mathrm{g} / \mathrm{kg} / \mathrm{min}$ infusion for 48 $72 \mathrm{~h})$, high-dose $(100 \mu \mathrm{g} / \mathrm{kg}$ bolus plus $3 \mu \mathrm{g} / \mathrm{kg} / \mathrm{min}$ infusion for 48-72 h) argatroban or heparin as adjunct therapy to $\mathrm{tPA}(\mathrm{n}=125)$.

The primary efficacy outcome (rate of TIMI grade 3 flow at $90 \mathrm{~min}$ ) was achieved in $42.1 \%$ of heparin, $56.8 \%$ of low-dose argatroban ( $\mathrm{p}=0.20 \mathrm{vs}$. heparin) and $58.7 \%$ of high-dose argatroban patients ( $\mathrm{p}=0.13 \mathrm{vs}$. heparin) (table 5 ). In patients presenting after $3 \mathrm{~h}$, TIMI grade 3 flow was significantly more frequent in high-dose argatroban than heparin patients (57.1 vs. $20.0 \%$; $\mathrm{p}=0.03$ ). Major bleeding was observed in $10.0 \%$ of heparin, and in 2.6 and $4.3 \%$ of low-dose and high-dose argatroban patients. The composite endpoint (death, recurrent MI, cardiogenic shock, congestive heart failure, revascularization, recurrent ischemia at 30 days) occurred in $37.5 \%$ of heparin, $32.0 \%$ of low-dose and $25.5 \%$ of high-dose argatroban patients $(\mathrm{p}=0.23)$.

A second study was conducted which compared argatroban to heparin as adjunct therapy to alteplase (tPA) for the treatment of acute MI [66]. The ARGAMI (Argatroban in Acute Myocardial Infarction) study was an open dosefinding study $(\mathrm{n}=35)$, followed by a placebo-controlled study with a double-dummy technique and a 2:1 (argatroban, $n=82$ :heparin, $n=45$ ) randomization. An argatroban dose of $100 \mu \mathrm{g} / \mathrm{kg}$ bolus plus $3 \mu \mathrm{g} / \mathrm{kg} / \mathrm{min}$ infusion for $72 \mathrm{~h}$ was selected for the randomized study. TIMI grade 2 or 3 flow after $90 \mathrm{~min}$, not different between treatment groups, was obtained in $76 \%$ of the argatroban patients and in $82 \%$ of the heparin patients (not significant). Coronary angiography after $24 \mathrm{~h}$ and at 5-10 days showed similar low reocclusion rates in both groups. Bleeding complications, similar in both groups, were observed in $19.5 \%$ of the argatroban and in $20.0 \%$ of the heparin patients.

\section{Summary}

The introduction of direct thrombin inhibitor drugs, such as argatroban, has added a new dimension to the management of thrombosis (table 6). These drugs offer a unique substitute for anticoagulation in patients who are heparin compromised, a position we have not had prior to now. Based on clinical studies that have demonstrated the efficacy in patients with HIT, argatroban has been approved in the US for both prophylaxis and treatment of thrombosis in patients with HIT. 
Table 6. Clinical uses of argatroban

Approved

Prophylaxis against thrombosis in patients with heparin-induced thrombocytopenia

Treatment of thrombosis in patients with heparin-induced thrombocytopenia

Anticoagulation for patients with heparin-induced thrombocytopenia undergoing percutaneous coronary interventions

\section{Under investigation}

Interventional cardiology procedures

Angioplasty

Stent implants

Adjunct to thombolysis

Peripheral vascular procedures

Cerebral vascular procedures

Treatment of thrombotic stroke

Other thrombotic disorders

Hemodialysis the shorter-acting hirudin derivative, hirulog, was shown to be associated with both a lower incidence of ischemia and unstable angina and a decreased bleeding rate compared to heparin. Data from the CACHET trial showed a decrease in combined endpoints using DTIs during coronary intervention.

Limited studies suggest that argatroban will provide reliable anticoagulation during PCI and during peripheral vascular interventions in both large and small vessels in HIT patients. In patients with and without HIT procedural success rates similar to that of heparin were demonstrated. Argatroban has also been used in HIT patients with unstable angina and for the treatment of AMI as an adjunct to thrombolysis. Similar clinical outcomes to heparin-treated patients and no significant differences for major hemorrhage were observed with argatroban.

The main attributes of argatroban are its rapid onset of action, the fast reversibility of its anticoagulant effect, inhibition of clot-bound thrombin and no need for dosage adjustment in patients with renal impairment (tables $1,2)$. Argatroban is easily monitored by the aPTT for low doses and the ACT for high doses. These properties make argatroban a predictable, safe, easy to dose anticoagulant. Argatroban will continue to be studied as an antithrombotic agent in additional clinical settings such as ischemic and thrombotic stroke and as an adjunct anticoagulant for various indications.

\section{References}

1 Jeske W, Walenga JM, Lewis BE, Fareed J: Pharmacology of argatroban. Exp Opin Invest Drugs 1999;8:625-654.

2 Hursting MJ, Alford KL, Becker JC, Brooks RL, Joffrion JL, Knappenberger GD, Kogan PW, Kogan TP, McKinney AA, Schwarz RP: Novastan (brand of argatroban): A small-molecule, direct thrombin inhibitor. Semin Thromb Hemost 1997;23:503-516.

3 Bush LR: Argatroban, a selective, potent thrombin inhibitor. Cardiovasc Drug Rev 1991;9:247-263.

4 Hijikata-Okunomiya A, Okamoto S: A strategy for a rational approach to designing synthetic selective inhibitors. Semin Thromb Hemost 1992;18:135-149.

5 Berry CN, Girard D, Lochot S, Lecoffre C: Antithrombotic actions of argatroban in rat models of venous, mixed and arterial thrombosis, and its effects on the tail transection bleeding time. Br J Pharm 1994;113:1209-1214.
6 Amiral J, Bridey F, Wolf M, Boyer-Neumann C, Fressinaud E, Vissac AM, Peynaud-Debayle E, Dreyfus M, Meyer D: Antibodies to macromolecular platelet factor 4-heparin complexes in heparin-induced thrombocytopenia: A study of 44 cases. Thromb Haemost 1995;73:21-28.

7 Greinacher A, Pötzsch B, Amiral J, Cummel V, Eichner A, Mueller-Eckhardt C: Heparin-associated thrombocytopenia: Isolation of the antibody and characterization of a multi-molecular PF-4 heparin complex as the major antigen. Thromb Haemost 1994;71:247-251.

8 Kelton, JG, Smith JW, Warkentin TE, Hayward CPM, Denomme GA, Horsewood P: Immunoglobulin $G$ from patients with heparininduced thrombocytopenia binds to a complex of heparin and platelet factor 4. Blood 1994;83: 3232-3239.

9 Brandt JT, Isenhart CE, Osborne JM, Ahmed A, Anderson CL: On the role of platelet FcRIIA phenotype in heparin-induced thrombocytopenia. Thromb Haemost 1995;74:1564-1572.

10 Aster RH: Heparin-induced thrombocytopenia and thrombosis. N Engl J Med 1995;332:13741376.
11 Greinacher A, Michels I, Liebenhoff U, Presek $\mathrm{P}$, Mueller-Eckhardt C: Heparin-associated thrombocytopenia: Immune complexes are attached to the platelet membrane by the negative charge of highly sulfated oligosaccharides. Br J Haematol 1993;84:711-716.

12 Walenga JM, Koza MJ, Lewis BE, Pifarré R: Relative heparin induced thrombocytopenic potential of low molecular weight heparins and new antithrombotic agents. Clin Appl Thromb Hemost 1996;2(suppl 1):S21-S27.

13 Cines DB, Tomaski A, Tannenbaum S: Immune endothelial-cell injury in heparin associated thrombocytopenia. N Engl J Med 1987; 316:581-589.

14 Visentin GP, Ford SE, Scott JP, Aster RH: Antibodies from patients with heparin-induced thrombocytopenia/thrombosis are specific for platelet factor 4 complexed with heparin or bound to endothelial cells. J Clin Invest 1995; 93:81-88.
Argatroban in HIT Type II and Acute

Coronary Syndrome
Pathophysiol Haemost Thromb

2002;32(suppl 3):46-55 
15 Herbert J-M, Savi P, Jeske WP, Walenga JM: Effect of SR 121566A, a potent GPIIb/IIIa antagonist, on the HIT serum/heparin-induced platelet mediated activation of human endothelial cells. Thromb Haemost 1998;80:326331.

16 Pouplard C, Iochmann S, Renard B, Herault O, Colombat P, Amiral J, Gruel Y: Induction of monocyte tissue factor expression by antibodies to heparin-platelet factor 4 complexes developed in heparin-induced thrombocytopenia. Blood 2001;97:3300-3302.

17 Jeske WP, Walenga JM, Szatkowski E, Ero M, Herbert JM, Bakhos M: Effect of glycoprotein IIb/IIIa antagonists on the HIT serum induced activation of platelets. Thromb Res 1997;88 271-281.

18 Warkentin TE, Hayward CPM, Boshkov CK, Santos AV, Sheppard JI, Bode AP, Kelton JG: Sera from patients with heparin-induced thrombocytopenia generate platelet-derived microparticles with procoagulant activity: An explanation for the thrombotic complications of heparin-induced thrombocytopenia. Blood 1994;84:3691-3699.

19 Walenga JM, Lewis BE, Jeske WP, Leya F, Wallis DE, Bakhos M, Fareed, J: Combined thrombin and platelet inhibition treatment for HIT patients. Hämostaseologie 1999;19:128133.

20 Jeske WP, Vasaiwala S, Schlenker R, Wallis E, Walenga JM: Leukocyte activation in heparininduced thrombocytopenia (abstract). Blood 2000;96:29b

21 Walenga JM, Jeske WP, Messmore HL: Mechanisms of venous and arterial thrombosis in heparin-induced thrombocytopenia. J Thromb Thrombolysis 2000;10(suppl 1):S13-S20.

22 Lewis BE, Walenga JM, Wallis DE: Anticoagulation with Novastan (argatroban) in patients with heparin-induced thrombocytopenia and heparin-induced thrombocytopenia and thrombosis syndrome. Semin Thromb Hemost 1997;23:197-202.

23 Messmore HL, Upadhyay G, Farid S, Parachuri R, Wehrmacher W, Godwin J: Heparininduced thrombocytopenia and thrombosis in cardiovascular surgery; in Pifarré R (ed): New Anticoagulants for the Cardiovascular Patient. Philadelphia, Hanley \& Belfus, 1993, pp 8394.

24 Walenga JM, Lewis BE, Hoppensteadt DA, Fareed J, Bakhos M: Management of heparininduced thrombocytopenia and heparin-induced thrombocytopenia and thrombosis syndrome. Clin Appl ThrombHemost 1997;3 (suppl 1):S53-S63.

25 Moberg P, Geary V, Sheikh M: Heparin-induced thrombocytopenia: A possible complication of heparin-coated pulmonary artery catheters. J Cardiothorac Vasc Anesth 1990;4:266.

26 Wallis DE, Workman DL, Lewis BE, Steen L, Pifarré R, Moran JF: Failure of early heparin cessation as treatment for heparin-induced thrombocytopenia. Am J Med 1999;106:629_ 635.
27 Warkentin T, Kelton J: A 14-year study of heparin-induced thrombocytopenia. Am J Med 1996;101:502-507.

28 Walenga JM, Jeske WP, Wood JJ, Ahmad S, Lewis BE, Bakhos M: Laboratory tests for heparin-induced thrombocytopenia: A multicenter study. Semin Hematol 1999;36(suppl 1):2228.

29 Walenga JM, Jeske WP, Fasanella AR, Wood JJ, Bakhos M: Laboratory tests for the diagnosis of heparin-induced thrombocytopenia. Semin Thromb Hemostas 1999;25(suppl 1): 43-49.

30 Lindhoff-Last E, Eichler P, Stein M, Plagemann J, Gerdsen F, Wagner R, Ehrly AM, Bauersachs R: A prospective study on the incidence and clinical relevance of heparin-induced antibodies in patients after vascular surgery. Thromb Res 2000;97:387-393.

31 Warkentin TE, Levine MN, Hirsh J, Horsewood P, Roberts RS, Gent M, Kelton JG: Heparin-induced thrombocytopenia in patients treated with low-molecular-weight heparin or unfractionated heparin. N Engl J Med 1995; 332:1330-1335.

32 Bauer TL, Arepally G, Konkle BA, Mestichelli B, Shapiro SS, Cines DB, Poncz M, McNulty S, Amiral J, Hauck WW, Edie RN, Mannion JD: Prevalence of heparin-associated antibodies without thrombosis in patients undergoing cardiopulmonary bypass surgery. Circulation 1997;95:1242-1246.

33 Prechel M, Bano A, Drenth AF, Messmore HL, Walenga JM: Assay selection and interpretation for laboratory testing of heparin-induced thrombocytopenia: Diagnostic implications. Blood 2001;98:36a.

34 Wallis DE, Quintos R, Wehrmacher W, Messmore H: Safety of warfarin anticoagulation in patients with heparin-induced thrombocytopenia. Chest 1999;116:1333-1338.

35 Rao RC, Lewis BE, Johnson SA: Thrombolytic experience for treatment of thrombosis in patients with post-operative heparin-induced thrombocytopenia (abstract). Blood 1995;86 (suppl 1):551a.

36 Cohen JI, Cooper MR, Greenberg CS: Streptokinase therapy of pulmonary emboli with heparin-associated thrombocytopenia. Arch Intern Med 1985;135:1725-1726.

37 Cole CW, Bormanis J: Ancrod: A practical alternative to heparin. J Vasc Surg 1988;8:5963.

38 Lewis BE, Leya FS, Wallis D, Grassman E: Failure of ancrod in the treatment of heparininduced arterial thrombosis. Can J Cardiol 1994;10:559-561.

39 Magnani HN: Heparin-induced thrombocytopenia (HIT): An overview of 230 patients treated with Orgaran (Org 10172). Thromb Haemost 1993;70:554-561.

40 Haas S, Walenga JM, Jeske WP, Fareed J: Heparin-induced thrombocytopenia: Clinical considerations of alternative anticoagulation with various glycosaminoglycans and thrombin inhibitors. Clin Appl Thromb Hemost 1999;5: 52-59.
41 Greinacher A, Feigl M, Mueller-Eckhardt C: Cross-reactivity studies between sera of patients with heparin associated thrombocytopenia and a new low molecular weight heparin, reviparin. Thromb Haemost 1994;72:644645.

42 Lewis BE, Wallis DE, Berkowitz SD, Matthai WH, Fareed J, Walenga JM, Bartholomew J, Sham R, Lerner RG, Zeigler ZR, Rustagi PK, Jang IK, Rifkin SD, Moran J, Hursting MJ, Kelton JG, for the ARG-911 Study Investigators: Argatroban anticoagulant therapy in patients with heparin-induced thrombocytopenia. Circulation 2001;103:1838-1843.

43 Greinacher A, Volpel H, Janssens U, HachWunderle V, Kemkes-Matthes B, Eichler P, Mueller-Velten HG, Pötzsch B, for the HIT Investigators Group: Recombinant hirudin (lepirudin) provides safe and effective anti-coagulation in patients with heparin-induced thrombocytopenia: A prospective study. Circulation 1999;99:73-80.

44 Greinacher A, Janssens U, Berg G, Bock M, Kwasny H, Kemkes-Matthes B, Eichler P, Volpel H, Pötzsch B, Luz M, for the Heparin-Associated Thrombocytopenia Study (HAT) investigators. Lepirudin (recombinant hirudin) for parenteral anticoagulation in patients with heparin-induced thrombocytopenia. Circulation 1999;100:587-593.

45 Izawa O, Katsuki M, Komatsu T, Iida S: Pharmacokinetics studies of argatroban (MD-805) in human - Concentrations of argatroban and its metabolites in plasma, urine and feces during and after drip intravenous infusion (in Japanese). Jpn Pharmacol Ther 1986;14 (suppl 5):251-263.

46 Bergougnan L, Moore N, Brohier S: Pharmacodynamic and pharmacokinetic profile of argatroban $(1 \mathrm{mg} / \mathrm{ml}$ alcohol solution) in healthy man. J Clin Pharmacol 1998:38:878.

47 Swan SK, Hursting MJ: The pharmacokinetics and pharmacodynamics of argatroban: Effects of age, gender, and hepatic or renal dysfunction. Pharmacotherapy 2000;20:318-329.

48 Swan SK, St Peter JV, Lambrecht LJ, Hursting MJ: Comparison of anticoagulant effects and safety of argatroban and heparin in healthy subjects. Pharmacotherapy 2000;20:756-770.

49 Eichler P, Friesen H-J, Lubenow N, Jaeger B, Greinacher A: Anti-hirudin antibodies in patients with heparin-induced thrombocytopenia treated with lepirudin: Incidence, effects on aPTT, and clinical relevance. Blood 2000;96: 2373-2378.

50 Walenga JM, Ahmad S, Hoppensteadt D, Iqbal $\mathrm{O}$, Hursting MJ, Lewis BE: Argatroban therapy does not generate antibodies that alter its anticoagulant activity in patients with heparininduced thrombocytopenia. Thromb Res 2002; 105:401-405.

51 Walenga JM, Fasanella AR, Iqbal O, Hoppensteadt DA, Ahmad S, Wallis DE, Bakhos M: Coagulation laboratory testing in patients treated with argatroban. Semin Thromb Hemost 1999;25(suppl 1):61-66. 
52 Ahmad S, Ahsan A, Iqbal O, Hoppensteadt DA, Lewis BE, Walenga JM, Fareed J: Pharmacokinetics and pharmacodynamics of argatroban as studied by HPLC and functional methods: Implications in the monitoring and dosage-optimizations in cardiovascular patients. Clin Appl Thromb Hemost 1998;4:243-249.

53 Sheth SB, DiCicco RA, Hursting MJ, Montague T, Jorkasky DK: Interpreting the international normalized ratio (INR) in individuals receiving argatroban and warfarin. Thromb Haemost 2001;85:435-440.

54 Hursting MJ, Zehnder JL, Joffrion JL, Becker JC, Knappenberger GD, Schwarz RP: The interventional normalization ratio during concurrent warfarin and argatroban anticoagulation differential contributions of each agent and effects of the choice of the thromboplastin used. Clin Chem 1999;45:409-412.

55 Haas S, Walenga JM, Jeske WP, Fareed J: Heparin-induced thrombocytopenia: The role of platelet activation and therapeutic implications. Semin Thromb Hemost 1999;25 (suppl 1):67-75.

56 Lewis BE, Ferguson JJ, Grassman ED, Fareed J, Walenga JM, Joffrion JL, Wrona L, Johnson SA, Schwarz RP, McKiernan T: Successful coronary interventions performed with argatroban anticoagulation in patients with heparin-induced thrombocytopenia and thrombosis syndrome. J Invas Cardiol 1996;8:410-417.
57 Lewis BE, Iqbal O, Hoppensteadt D, Ahsan A, Ahmad S, Messmore HL, Schwarz RP, Walenga JM: Clinical pharmacokinetic and pharmacodynamic studies on argatroban to optimize the anticoagulant dosage in interventional cardiovascular procedures (abstract). Thromb Haemost 1997(suppl);492.

58 Lewis BE, Rangel Y, Fareed J: The first report of successful carotid stent implant using argatroban anticoagulation in a patient with heparin-induced thrombocytopenia and thrombosis syndrome: A case report. Angiology 1998;49: 61-67.

59 Lewis BE, Matthai WH Jr, Cohen M, Moses JW, Hursting MJ, Leya F, ARG-216/310/311 Study Investigators: Argatroban anticoagulation during percutaneous coronary intervention in patients with heparin-induced thrombocytopenia. Catheter Cardiovasc Interv 2002; 57:177-184.

60 Itoh T, Nonogi H, Miyazaki S, Itoli A, Daikoko $\mathrm{S}$ : Local delivery of argatroban using drug delivery device 'dispatch' in the prevention of restenosis following coronary angioplasty trial (40-CAT): Result of the prospective randomized pilot study. Circulation 1997;96:3635.

61 Kobayashi H, Suzuki S, Sakamoto S, Matsuo $\mathrm{T}$ : Argatroban, a direct thrombin inhibitor versus heparin during and after percutaneous transluminal coronary angioplasty (PTCA) (abstract). Thromb Haemost 1997(suppl);494.
62 Herrman JP, Suryapranata H, den Heijer P, Gabriel L, Kutryk MJB, Serruys PW: Argatroban during percutaneous transluminal coronary angioplasty: Results of a dose-verification study. J. Thromb Thrombolysis 1996;3:367375.

63 Lewis BE, Grassman ED, Wrona L, Rangel Y: Novastan anticoagulation during renal stent implant in a patient with heparin-induced thrombocytopenia. Blood Coagul Fibrinolysis 1997;8:54-58.

64 Kobayashi S, Tazaki Y: Effect of the thrombin inhibitor argatroban in acute cerebral thrombosis. Semin Thromb Hemost 1997;23:531534.

65 Jang IK, Brown DF, Giugliano RP, Anderson HV, Losordo D, Nicolau JC, Dutra OP, Bazzino O, Viamonte VM, Norbady R, Liprandi AS, Massey TJ, Dinsmore R, Schwarz RP: A multicenter, randomized study of argatroban versus heparin as adjunct to tPA in acute MI: MI with novastan and tPA study (MINT). J Am Coll Cardiol 1999;33:1879-1885.

66 Vermeer F, Vahanian A, Fels PW, Besse P, Muller E, van deWerf F, Fitzgerald D, Darius H, Puel J, Garrigou D, Simoons ML: Argatroban and alteplase in patients with acute myocardial infarction: The ARGAMI study. J Thromb Thrombolysis 2000;10:233-240.
Argatroban in HIT Type II and Acute

Coronary Syndrome
Pathophysiol Haemost Thromb

2002;32(suppl 3):46-55 